\title{
Peningkatan Kinerja Berbagai Kompor Dengan Bahan Bakar Briket Limbah Tempurung Kelapa
}

\author{
Petrus Sampelawang *, Sallolo Suluh ** \\ * Teknik Mesin Fakultas Teknik Universitas Kristen Indonesia Toraja
}

\begin{abstract}
Pemanfaatan briket biomassa yang efektif dan efisien sangat dipengaruhi oleh jenis kompor yang digunakan dan cara penggunaannya. Penelitian ini bertujuan untuk membuat briket arang tempurung kelapa sebagai bahan bakar kompor, melakukan pengujian proksimasi, nilai kalor dan sifat fisik kemudian menguji kinerja berupa temperature, kemampuan mendidihkan air dan efisiensi pada 3 jenis kompor sebelum dan setelah modifikasi. Metode penelitian yang digunakan adalah metode eksperimental dengan memanfaatkan briket arang limbah tempurung kelapa sebagai bahan bakar pada 3 jenis kompor yang berbeda sebelum dan setelah modifikasi. Hasil uji komposisi kimia dengan analisis proksimasi rata-rata yaitu kadar air 1.67\%, kadar abu $13.03 \%$, volatile matters 28.69\%, fixed carbon 56.69\%. Nilai kalor didapatkan sebesar $4949 \mathrm{kkal} / \mathrm{kg}$, kuat tekan sebesar $0.489 \mathrm{gr} / \mathrm{cm} 2$ dan kerapatannya sebesar $0.705 \mathrm{gr} / \mathrm{cm} 3$. Hasil uji pembakaran pada 3 jenis kompor yang berbeda sebelum dan sesudah modifikasi menunjukkan bahwa kompor K'1dan kompor K'3 merupakan 2 jenis (kode) kompor briket yang paling unggul dalam hal kemampuan untuk mendidihkan dan efisiensi pembakaran setelan modifikasi (kompor K'1 sebesar 71.30 \% dan kompor K'3 sebesar 70.73\%). Kedua kompor tersebut memiliki keunggulan masing-masing. Khususnya kompor K'3 dapat di produksi secara lokal (dari tanah liat) dan harganya terjangkau.
\end{abstract}


Ketiga kompor mngalami peningkatan kinerja yang sangat signifikan setelah dilakukan modifikasi.

Kata kunci : briket arang tempurung kelapa, komposisi kimia, nilai kalor, sifat fisik, dan efisiensi kompor

Pemanfaatan briket biomassa yang efektif dan efisien sangat dipengaruhi oleh jenis kompor yang digunakan dan cara penggunaannya. Penelitian ini bertujuan untuk membuat briket arang tempurung kelapa sebagai bahan bakar kompor, melakukan pengujian proksimasi, nilai kalor dan sifat fisik kemudian menguji kinerja berupa temperature, kemampuan mendidihkan air dan efisiensi pada 3 jenis kompor sebelum dan setelah modifikasi. Metode penelitian yang digunakan adalah metode eksperimental dengan memanfaatkan briket arang limbah tempurung kelapa sebagai bahan bakar pada 3 jenis kompor yang berbeda sebelum dan setelah modifikasi. Hasil uji komposisi kimia dengan analisis proksimasi rata-rata yaitu kadar air 1.67\%, kadar abu $13.03 \%$, volatile matters $28.69 \%$, fixed carbon $56.69 \%$. Nilai kalor didapatkan sebesar $4949 \mathrm{kkal} / \mathrm{kg}$, $\mathrm{kuat}$ tekan sebesar $0.489 \mathrm{gr} / \mathrm{cm}^{2}$ dan kerapatannya sebesar $0.705 \mathrm{gr} / \mathrm{cm}^{3}$. Hasil uji pembakaran pada 3 jenis kompor yang berbeda sebelum dan sesudah modifikasi menunjukkan bahwa kompor K'1dan kompor K'3 merupakan 2 jenis (kode) kompor briket yang paling unggul dalam hal kemampuan untuk mendidihkan dan efisiensi pembakaran setelan modifikasi (kompor K'1 sebesar 71.30\% dan kompor K'3 sebesar 70.73\%). Kedua kompor tersebut memiliki keunggulan masing-masing. Khususnya kompor K'3 dapat di produksi secara lokal (dari tanah liat) dan harganya terjangkau. Ketiga kompor mngalami peningkatan kinerja yang sangat signifikan setelah dilakukan modifikasi.

Kata kunci : briket arang tempurung kelapa, komposisi kimia, nilai kalor, sifat fisik, dan efisiensi kompor

\section{Pendahuluan}

Indonesia dahulu dikenal sebagai salah satu negara OPEC, organisasi penghasil minyak dunia. Akan tetapi, sejak tahun 2003 Indonesia telah berubah menjadi Negara pengimpor minyak. Pada tahun 2005, konsumsi energi Indonesia sekitar 700 setara barel minyak (SBM) pertahun. Jumlah tersebut, sekitar $57 \%$ energi berasal dari minyak bumi, $24 \%$ gas, $13 \%$ batubara, dan sisanya dari tenaga air, panas bumi, dan sebagainya. (Prawiroadmodjo dan armando, 2005).

Akibat dampak krisis ekonomi yang berkepanjangan, kondisi tersebut di atas berubah secara drastis ketika subsidi BBM mulai dikurangi secara bertahap. Beberapa lapisan masyarakat, bukan hanya kelas bawah melainkan juga kelas menengah dan industri rumah tangga, mulai merasakan beratnya beban dengan dihilangkannya BBM yang bersubsidi. Dari fakta dan data yang menunjukkan bahwa pemakaian bahan bakar fosil kian mendekati akhir, karna jumlah cadangan minyak semakin menipis. Harga minyak bumi yang tidak stabil dan terus meningkat. Ikuti isu-isu bahwa bahan bakar fosil menjadi penyebab terjadinya kerusakan lingkungan sudah mulai terbukti. Seiring dengan pertumbuhan penduduk dunia yang terus meningkat, mendorong manusia mencari alternatif sumber energi baru dengan memanfaatkan sumber energi yang dapat diperbaharui (renewable energy). Beberapa jenis sumber energi yang dapat diperbaharui dan dapat dikembangkan antara lain energi matahari, energi panas laut (OTEC) dan energi 
biomassa. Biomassa atau bahan-bahan organik ini dapat diolah dandijadikan sebagai bahan bakar alternatif contonya dengan pembuatan briket.

Arang tempurung kelapa adalah produk yang diperoleh dari pembakaran tidak sempurna dari tempurung kelapa. Arang memberikan kalor yang lebih tinggi dan asap yang lebih sedikit, arang dapat dihaluskan kemudian dikempa menjadi briket dalam berbagai macam bentuk, dimana penggunaan briket ini akan lebih praktis, hemat dan ekonomis serta mudah di dapatkan dibanding kayu bahar.

Adapun penelitian-penelitian yang dilakukan sehubungan dengan briket tempurung kelapa yang mempunyai nilai lebih dari briket biomassa yang lain yaitu, Siti Jamilatun (2008 dan 2011) didapatkan bahwa briket tempurung kelapa paling optimum dan bahan bakar alternatif yang ekonomis dimana nilai kalor yang cukup tinggi $5779.11 \mathrm{kkal} /$ gram, massa 250 gram dengan nyala api yang cukup tinggi dengan lama waktu penyalaan 116 menit dan kadar volatil yang tinggi dapat dikondensasikan dan dimanfaatkan untuk membuat asap cair sebagai pengawet dibandingkan dengan briket batubara dan arang kayu. Herotje Siwi (2010) mendapatkan nilai kalor briket tempurung kelapa $4569.22 \mathrm{kkal} / \mathrm{gram}$. Meli dan Muslimin (2010) didapatkan nilai kalor tempurung kelapa sebesar $5410.77 \mathrm{kkal} / \mathrm{gram}$. Nilai kalor yang berbeda-beda dari beberapa penelitian sebelumnya kemungkinan karena, proses pembuatan yang berbeda dan komposisi bahan briket yang digunakan. Esmar Budi (2011) didapatkan arang tempurung kelapa memiliki kandungan karbon sebanyak $76.32 \%$ yang berpotensi baik dijadikan sebagai bahan bakar.

Berdasarkan pertimbangan diatas energi biomassa dalam bentuk briket tempurung kelapa akan dimanfaatkan sebagai bahan bakar pada berbagai kompor briket. Dan memodifikasi berbagai kompor batubara tersebut untuk memperbaiki kinerjanya dalam meningkatkan efektifitas dan efisiensi bahan bakar alternatif untuk meringankan beban dari pemerintah khususnya masyarakat yang telah kesulitan untuk mencari minyak tanah. Bertitik tolak dari uraian tersebut diperlukan pengkajian tentang studi kemungkinan peningkatan kinerja berbagai kompor dengan bahan bakar briket limbah biomassa untuk mengurangi ketergantungan pada minyak bumi khususnya minyak tanah, dan mencari energi alternatif yang lebih murah.

\section{LANDASAN TEORI}

Kompor briket adalah alat memasak yang menggunakan bahan bakar dari briket, yaitu bahan padat yang telah yang diproses baik dengan proses karbonisasi maupun tanpa karbonisasi yang berasal dari batubara ataupun dari biomassa sejenisnya . Dan saat ini, penggunaan sudah tidak asing lagi, karena adanya anjuran dari pemerintah untuk diversifikasi energi. Apalagi cadangan batubara di Indonesia sangat melimpah, demikian juga halnya biomassa. Kompor briket yang digunakan dalam penelitian ini adalah jenis kompor briket yang berdasarkan bahan pembuatnya, bahan baku pembuat kompor sangat mempengaruhi penampilan, ketahanan serta kualitas pemanfaatan panasnya. Adapun jenis-jenisnya terdiri atas :

1. Kompor britubara merupakan salah satu jenis kompor yang dilapisi bahan baku tahan api, lebih tahan panas. Namun, bila dalam penggunaannya tidak hati-hati akan mudah pecah dan kompor ini tidak dapat digunakan lagi. Selanjutnya disebut sebagai kompor K1

2. Kompor KM adalah kompor briket yang terbuat dari bahan logam bersifat tahan lama, tetapi juga dapat berkarat sehingga penampilannya berubah seiring dengan lamanya pemakaian. Selanjutnya disebut sebagai kompor K2.

3. Tungku tanah liat atau yang disebut juga dengan anglo yang terbuat dari bahan baku gerabah, yaitu tanah liat yang dibakar, banyak terdapat di masyarakat dan umumnya digunakan sebagian besar masyarakat pedesaan. Selanjutnya disebut sebagai kompor K3 ${ }^{[1]}$.

Kelapa (Cocos nucifera) adalah tanaman yang tumbuh di daerah tropis dan dataran rendah yang sekarang telah menjadi tanaman perkebunan industri. Tumbuhan dari suku palmae ini memiliki batang lurus dan satu-satunya spesies dalam genus cocos. Tumbuhan ini diperkirakan berasal dari dari pesisir Samudera Hindia di sisi Asia, namun telah banyak menyebar luas diseluruh pantai tropika dunia. Kelapa juga merupakan pohon serbaguna bagi masyarakat tropika $^{[2]}$. 
Bahan bakar briket didefinisikan sebagai bahan bakar yang dihasilkan dari bahan-bahan organik melalui pemadatan, pengarangan eksternal, karbonasi lengkap atau gabungan. Pembriketan menurut Abdullah et all (1991) pada dasarnya densifikasi atau pemadatan bertujuan untuk memperbaiki sifat fisik suatu bahan sehingga memudahkan penanganannya ${ }^{[3]}$.

Menurut bossel (1994), bahan biomassa yang digunakan untuk pembuata briket berasal dari

1. Limbah pengolahan kayu seperti : logging residues, bark, saw dusk, shavinos, waste timber.

2. Limbah pertanian seperti : jerami, ampas tebu, daun kering

3. Limbah bahan berserat seperti: serat kapas, goni, sabuk kelapa

4. Limbah pengolahan pangan seperti kulit kacang-kacangan, biji buah-buahan, kulit buah-buahan,

5. Sellulosa seperti, limbah kertas, karton.

Menurut bentuknya, briket dibedakan menjadi 2 tipe bentuk, yaitu tipe yontan dan tipe telor (egg).

1) Tipe silinder (Yontan), untuk keperluan rumah tangga. Tipe briket ini lebih dikenal dan populer, berbentuk silinder dengan satu lubang besar ditengahnya dan 4 (empat) lubang kecil.

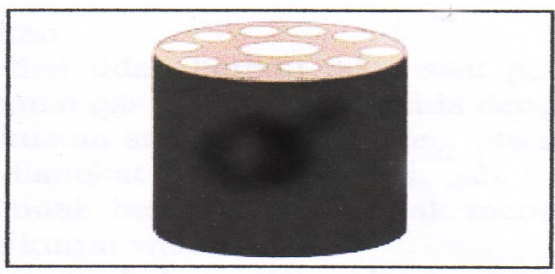

\section{Gambar 1. Briket tipe silinder (sarang tawon)}

2) Tipe telor (egg), untuk industri rumah tangga. Tipe briket ini biasanya digunakan untuk pembakaran kapur, bata, genteng, gerabah, pandai besi. Briket ini berbentuk oval dengan ukuran yang disesuaikan $^{[4] \text {. }}$

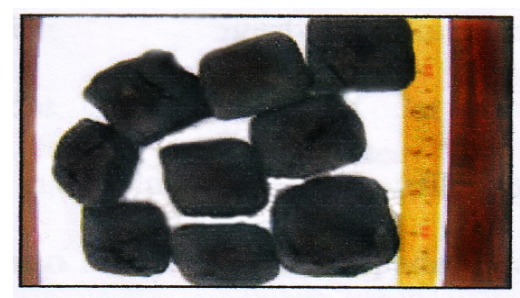




\section{Gambar 2. Briket tipe telor}

Beberapa faktor yang dijadikan standar briket arang menurut Enik Sri Widiarti (2010), antara lain: ${ }^{[5]}$ a. Kadar air (moisture)

Kandungan air dalam bahan bakar, air yang terkandung dalam kayu atau produk kayu dinyatakan sebagai kadar air (Haygreen dkk, 1995).

b. Kada abu $(A s h)$

Abu atau disebut juga bahan mineral yang terkandung dalam bahan bakar padat yang merupakan bahan yang tidak dapat terbakar setelah proses pembakaran. Abu adalah bahan yang terbakar apabila bahan padat (kayu) (Earl, 1974).

c. Zat-zat yang mudah menguap (Volatile matters)

Zat-zat yang mudah menguap (Volatile matters) merupakan salah satu karakterlistik yang terkandung dari suatu briket. Semakin banyak kandungan volatile matters pada bio briket, maka semakin mudah biobriket untuk terbakar dan menyala sehingga laju pembakaran semakin cepat.

d. Karbon tetap (Fixed carbon)

Kandungan fixed carbon atau biasa disebut juga kandungan carbon tetap (KT) yang terdapat pada bahan bakar yang berupa arang (char), yaitu komponen yang bila terbakar tidak membentuk gas.

e. Nilai kalor (Heating value/calorific value)

Nilai kalor bahan bakar adalah jumlah panas yang dihasilkan dan ditimbulkan oleh satu gram bahan bakar tersebut dengan meningkatkan temperatur satu gram air dari $3.5^{\circ} \mathrm{C}-4.5{ }^{\circ} \mathrm{C}$, dengan satuan kalori.

Beberapa Negara memberikan standar mutu briket arang seperti tabel 2.1. dibawah ini :

Tabel 1. Standar mutu briket arang ${ }^{[6]}$

\begin{tabular}{|l|l|l|l|l|l|}
\hline \multirow{2}{*}{ Sifat-sifat } & \multicolumn{4}{|l|}{ Standar Mutu } \\
\cline { 2 - 6 } & Komersial & Impor & Jepang & Inggris & USA \\
$1)$ & $2)$ & $3)$ & $4)$ & $5)$ \\
\hline $\begin{array}{l}\text { Moisure, } \\
\%\end{array}$ & 7.75 & $6-8$ & $6-8$ & $3-4$ & 3 \\
\hline
\end{tabular}




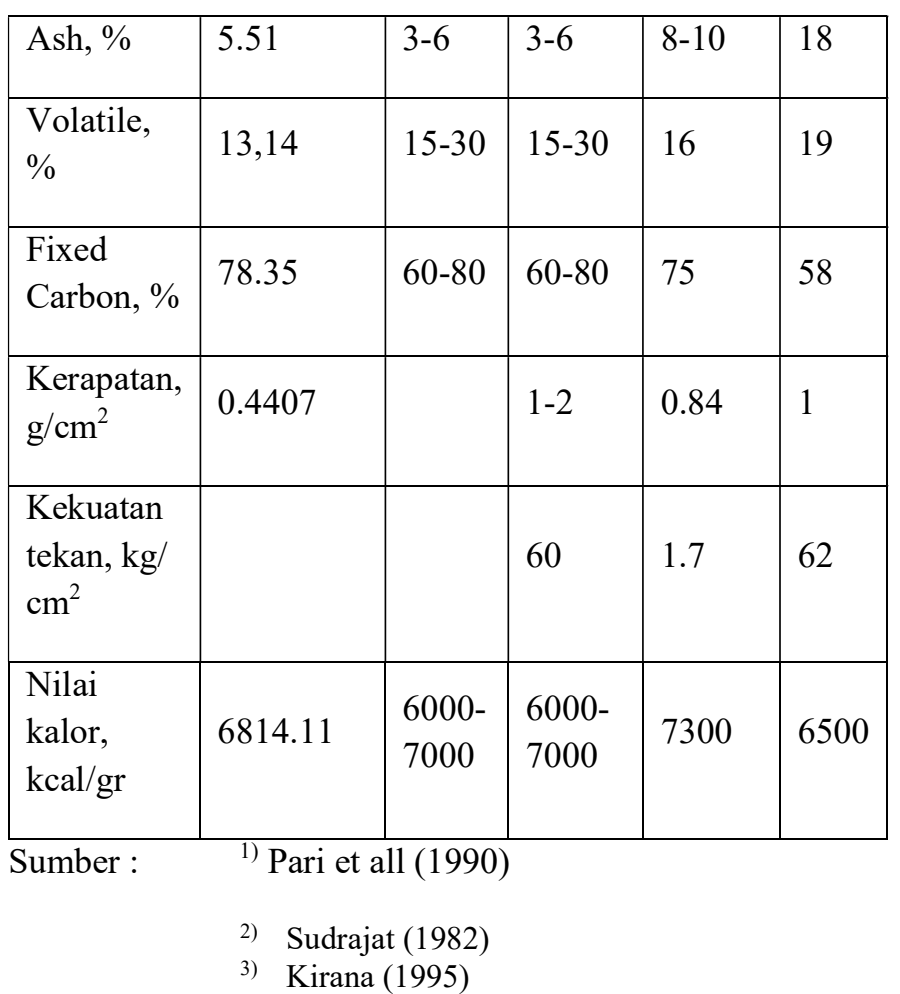

Lempung atau tanah liat merupakan tanah dengan butiran yang sangat halus, bersifat plastis (mudah dibentuk) dan mempunyai daya lekat.Tanah liat terbagi atas 2 jenis yaitu tanah liat primer dan tanah liat sekunder. Untuk jenis tanah liat yang digunakan dalam penelitian ini adalah jenis tanah liat sekunder. Hal ini di karenakan bentuk fisik briket, setelah pembakaran yang tersisa tanah liat berwarna coklat muda ketuaan merupakan ciri yang dimiliki oleh jenis tanah liat sekunder ${ }^{[5]}$

Tepung singkong (tepung tapioka) atau aci adalah tepung yang diperoleh dari umbi akar singkong. Tapioka memiliki sifat-sifat fisik yang serupa dengan tepung sagu, sehingga penggunaan keduanya dapat dipertukarkan. industri makanan, seperti dalam pembuatan pudding, sop, dan lain-lain

Pembakaran adalah reaksi cepat antara bahan bakar dari udara. Proses ini merupakan pelepasan energi termal dari bahan bakar. Energi termal ini dilepaskan selama reaksi pembakaran, dimana oksigen, $\mathrm{CO}_{2}$, air dan zat-zat lain yang terkandung dalam gas hasil pembakaran melalui pelepasan panas

\section{METODE PENELITIAN}

Penelitian ini dilaksanakan pada bulan Februari hingga April 2014 dengan cakupan kegiatan antara lain pengukuran dimensi ketiga kompor yang akan dimodifikasi, pembuatan briket arang tempurung kelapa dalam bentuk sarang tawon, pengujian proksimasi dan nilai kalor, pengujian sifat-sifat fisik serta pengujian pendidihan air dan pembakaran briket pada ketiga kompor yang berbeda sebelum dan setelah modifikasi untuk keperluan penelitian. Adapun usaha-usaha modifikasi untuk meningkatkan kinerja kompor dimaksudkan waktu masak yang lebih cepat dengan mendapatkan temperatur yang tinggi dengan meminimalkan kehilangan panas dan efisiensi tinggi dengan meminimalkan kehilangan panas. Proses pembuatan briket dan uji pembakaran dilakukan di Laboratorium Proses Produksi Teknik Unhas Makassar, pengujian proksimasi dan nilai kalor dilakukan Laboratorium Kimia Makanan Ternak Fakultas Peternakan Unhas dan pengujian fisik dilakukan di Laboratorium Ilmu Logam Fakultas Teknik UKIP Makassar. Keseluruhan data berupa waktu pembakaran, temperatur api, temperature air, temperature sekitar yang di tampilkan pada penelitian ini bersumber dari pengukuran pada 
eksperimen yang dilakukan di laboratorium, sedangkan rumus yang digunakan untuk menghitung Efisiensi thermal diperoleh dari beberapa buku referensi.

\section{A. Bahan dan Peralatan yang Digunakan}

Bahan dan peralatan yang digunakan pada penelitian ini adalah sebagai berikut :

1. Bahan :
a. Tempurung kelapa
b. Tepung tapioka
c. Tanah liat
d. Air

2. Peralatan

- Mesin cetak briket

- Mesin penggiling kopi

- Drum karbonisasi

- Ayakan (40-60 mesh)

- Kompor briket

- Thermokopel

- Timbangan

- Ketel air

- Bomb kalorimeter

- Panci aluminium

- Gelas ukur

B. Kompor yang dimodifikasi

Metode yang digunakan pada penelitian ini adalah metode eksperimen yaitu dengan memodifikasi 3 jenis kompor yang berbeda

1. Kompor Britubara (K1) yang dibuat oleh PT Britubara Indoraya Indonesia yang terbuat dari pelat baja yang dilapisi porselin, tahan panas $\left(1500^{\circ} \mathrm{C}\right)$, yang silinder permukaanya tahan panas. Adapun modifikasi yang dilakukan dengan penambahan 3 buah saluran udara yang semula hanya 1 saluran udara dengan dimensi yang berbeda. Dimana diameter masing-masing $30 \mathrm{~mm}$, jarak antara saluran udara satu dengan yang lain adalah $30 \mathrm{~mm}$. Tujuannya diharapkan udara yang masuk pada pembakaran menjadi lebih banyak untuk menghasilkan temperatur lebih tinggi dan waktu memasak yang lebih singkat. Foto dan sketsa modifikasi pada kompor K1 dapat dilihat pada Gambar 1 dibawah ini.
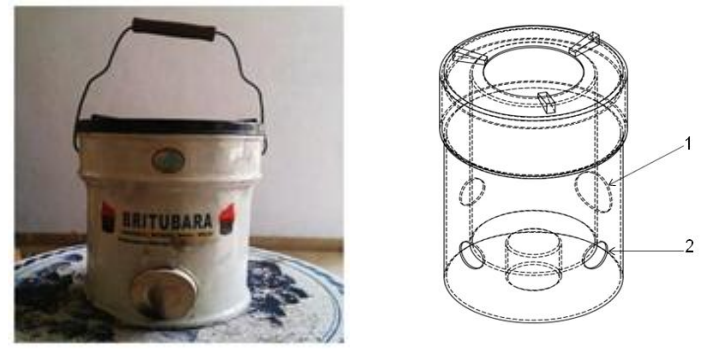

a. Kompor K1 sebelum modifikasi $\quad$ b. Sketsa Kompor K1 yang dimodifikasi

Gambar 3. Foto dan sketsa modifikasi kompor K1
2. Kompor KM (K2) didistribusikan oleh UD Barokah jalan ketilang no. 9 Makassar, Sulsel. Kompor ini terbuat dari pelat baja. Kompor ini akan dimodifikasi pada bagian luar dinding saluran udara kompor. Dengan menambahkan saluran udara 16 buah yang semula hanya 16 buah dengan diameter masing-masing 11 mm. Jarak antara masing-masing saluran udara satu dengan yang lainnya yaitu $31 \mathrm{~mm}$. Tujuannya dengan penambahan saluran udara ini, maka diharapkan semakin banyak udara yang masuk, sehingga pembakaran menjadi lebih baik untuk menghasilkan temperatur yang lebih tinggi dan waktu memasak yang lebih singkat. Foto dan
sketsa modifikasi dari kompor K2 dapat dilihat pada Gambar 2 dibawah ini. 

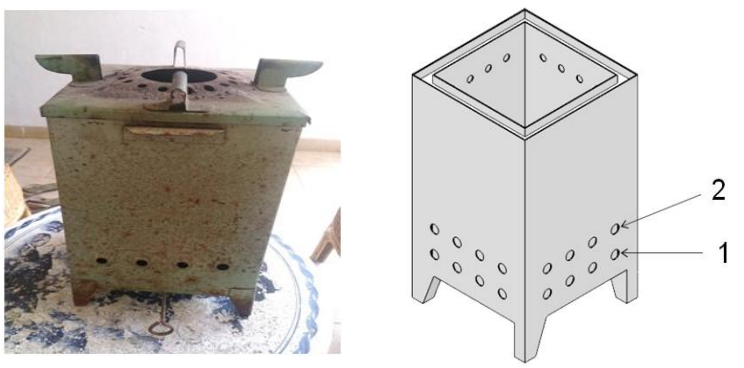

a. Foto kompor $\mathrm{K} 2$

b. Sketsa Kompor K1 yang dimodifikasi

Gambar 4. Foto dan sketsa modifikasi kompor K2

3. Kompor K3 dibuat Kompor/tungku tanah liat (K3) dibuat oleh pusat gerabah Takallar yang berbahan bakar arang kayu sebagai penganti kompor minyak tanah. Kompor ini terbuat dari tanah liat (gerabah) yang sangat efisiensi dan mudah didapatkan dipasar-pasar tradisonal. Kompor ini akan dimodifikasi dengan menambahkan silinder yang terbuat dari plat aluminium dengan ketebalan $0,9 \mathrm{~mm}$, diameter $90 \mathrm{~mm}$ dengan tinggi $140 \mathrm{~mm}$ dengan membuat saluran-saluran udara 1 baris, 2 baris

dan 3 baris lubang udara yang mengelilingi silinder tersebut. Diameter setiap saluran udara yang dibuat masing-masing $10 \mathrm{~mm}$ dan jarak antara lubang udara satu dengan yang lainnya adalah $20 \mathrm{~mm}$. Tujuannya untuk menambahkan isolasi dengan jalan mengurangi kehilangan panas ke dinding arah radial. Foto dan sketsa modifikasi dari kompor K3 dapat dilihat pada Gambar 3 dibawah ini.

Adapun kode kompor pengujian yang digunakan sebelum dan sesudah modifikasi pada berbagai kompor briket dapat dilihat pada tabel 3 di bawah ini :

\begin{tabular}{|c|c|c|c|}
\hline $\mathbf{N}$ & KodeKompor & Kepanjangan & \\
\hline 1 & $\mathrm{~K} 1$ & Kompor Bitubara & \\
\hline 2 & K1 & $\begin{array}{l}\text { modfikas nentup3 lubangudaraditambah } \\
\text { silinder satu baris lubangdibagianatas }\end{array}$ & \\
\hline 3 & $\mathrm{~K} 2$ & KomparKM & \\
\hline 4 & $\mathrm{~K} 2$ & $\begin{array}{l}\text { Modfikasi kampor KMdengan } \\
\text { mentuka24lubangudaraditambah }\end{array}$ & par 5. Foto dan \\
\hline 5 & $\mathrm{~K} 3$ & Kompar/Tungkutanahliat & \multirow{2}{*}{$\begin{array}{l}\text { Kompor/Tungku } \\
\text { tanahliat }\end{array}$} \\
\hline 6 & $\mathrm{~K} 3$ & $\begin{array}{l}\text { Tungkutanhliat dangan pananbahan } \\
\text { silinder stubaris lubangdibagianatas }\end{array}$ & \\
\hline
\end{tabular}

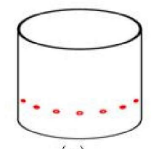

(a)

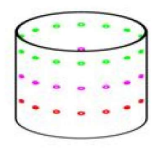

(c)

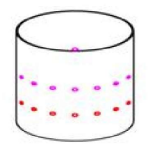

(b)

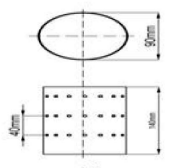

(d)

C. Prosedur Penelitian

1. Pembuatan briket arang tempurung kelapa dalam bentuk sarang tawon.

2. Pengujian analisis proksimasi terdiri atas kadar air (moisture), kadar abu (ash), volatile matters, fixed carbon dan nilai kalor

3. Pengujian fisik terdiri atas kuat tekan dan kerapatan (densitas)

4. Pengujian pembakaran briket dan pendidihan air pada 3 jenis kompor yang berbeda sebelum dan setelah modifikasi

a. Prosedur pembakaran briket dan pendidihan air pada kompor briket

b. Efisiensi pembakaran

Metode ini dilakukan dengan memanaskan sejumlah air sampai mendidih pada kompor dengan menggunakan briket tempurung sebagai bahan bakar secara. Volume air yang diukur dan massa bahan bakar briket yang digunakan dihitung, sehingga efisiensi termal dapat dihitung sebagai berikut dengan rumus berikut : 


$$
\begin{gathered}
\eta_{t h}=\frac{Q_{a i r}+Q_{\text {panci }}}{L H V \times M b b} \ldots(1) \\
\eta_{t h}=\frac{\left(M a \times C p_{\text {air }} \times\left(T_{a}-T_{b}\right)\right)+\left(M_{p} x C p_{a l} x\left(T_{c}-T_{b}\right)\right)+(M u x H l)}{L H V \times M b b} \ldots(2)
\end{gathered}
$$

dimana :

$\eta_{\text {th }} \quad$ : efisiensi termal pembakaran briket pada kompor briket (\%).

$\mathrm{M}_{\mathrm{a}} \quad$ : massa air mula-mula $(\mathrm{kg})$,

$\mathrm{M}_{\mathrm{bb}} \quad$ : massa briket yang telah terpakai dalam

pendidihan air $(\mathrm{kg})$.

$\mathrm{M}_{\mathrm{u}} \quad$ : massa uap air $(\mathrm{kg})$.

$\mathrm{H}_{L} \quad$ : Kalor laten dari uap $(\mathrm{kJ} / \mathrm{kg})$.

$\mathrm{Cp}_{\text {air }} \quad$ : kalor spesifik air $4.1769\left(\mathrm{~kJ} / \mathrm{kg}{ }^{0} \mathrm{C}\right)$.

$\mathrm{Cp}_{\mathrm{al}} \quad$ : kalor spesifik aluminium/bahan panci $\left(\mathrm{kJ} / \mathrm{kg}{ }^{0} \mathrm{C}\right)$.

$L H V$ : nilai kalor bawah briket $(\mathrm{kJ} / \mathrm{kg})$.

$\mathrm{T}_{\mathrm{b}} \quad$ : temperatur ambien dari air

$\mathrm{T}_{\mathrm{a}} \quad$ : temperatur uap $\operatorname{air}\left(100{ }^{\circ} \mathrm{C}\right)$

$\mathrm{T}_{\mathrm{c}} \quad$ : temperatur panci $\left({ }^{0} \mathrm{C}\right)$

A. Hasil Penelitian

\section{HASIL DAN PEMBAHASAN}

1. Pembuatan briket tempurung kelapa dalam bentuk sarang tawon.

Briket tempurung kelapa yang dibuat dalam bentuk sarang tawon, telah berhasil dibuat dengan menggunakan alat cetak seperti Gambar 4.1. dibawah ini. Sebelumnya telah dilakukan usaha perbaikan kualitas dengan cara memperbaiki proses pengarangan (mengurangi abu) dan proses pengeringan (mengurangi kadar air) serta penggunaan partikel arang yang optimal sebesar $40-60$ mesh.
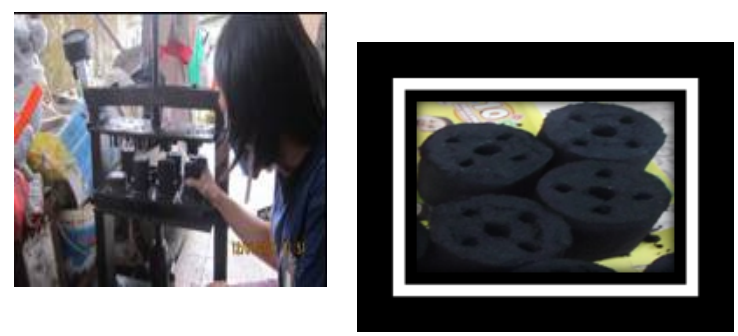
a. Alat cetak briket
b. Briket yang dihasilkan

\section{Gambar 6. Alat cetak dan briket yang dihasilkan}

Spesifikasi ukuran briket :

a) Briket bentuk silinder (sarang tawon)

Briket yang dihasilkan mempunyai dimensi rata-rata diameter $(\mathrm{d})=65 \mathrm{~mm}$, tinggi $(\mathrm{l})=45 \mathrm{~mm}$, diameter lubang tengah briket $(\mathrm{d})=15 \mathrm{~mm}$ dan diameter sekeliling $(\mathrm{d} 1)=8 \mathrm{~mm}$ (empat buah). 
b) Massa dan volume briket

Massa briketnya adalah $93.3 \mathrm{gr}$

Perhitungan volume briket :

$\mathrm{V}=$ Volume keseluruhan - volume lubang tengah $-4 \mathrm{x}$

volume lubang sisi

$=\left(3.14 \times 3.25^{2} \times 4,5\right)-\left(3.14 \times 0.75^{2} \times 4.5\right)-(4 \times(3.14 \mathrm{x}$

$\left.\left.0.4^{2} \times 4.5\right)\right)$

$=132.2568 \mathrm{~cm}^{3}$

2. Pengujian proksimasi dan nilai kalor

Pengujian proksimasi dan nilai kalor dilakukan di laboratorium kimia makanan ternak

Fakultas Peternakan Unhas dengan hasil dapat dilihat pada Tabel 4.

Tabel 3. Rekapitulasi hasil proksimasi dan nilai kalor

\begin{tabular}{|l|l|l|l|l|l|}
\hline \multirow{2}{*}{ No } & \multicolumn{3}{|l|}{ Komposisi (\%) } & \multirow{2}{*}{ Nilai kalor } \\
\cline { 2 - 5 } & Air & Abu & $\begin{array}{l}\text { Volatil } \\
\text { matter }\end{array}$ & $\begin{array}{l}\text { Fixed } \\
\text { Carbon }\end{array}$ & (Kkal/kg) \\
\hline 1. & 1.67 & 13.03 & 28.61 & 56.59 & 4949 \\
\hline
\end{tabular}

3. Pengujian fisik briket

Pengujian fisik terdiri atas 2 bagian yaitu :

1) Kekuatan Tekan

Untuk mendapatkan nilai tekan dari briket tempurung telah dilakukan penelitian di laboratorium Ilmu Logam UKIP Makassar dengan menggunakan alat Tensile test machine. Hasil dari gaya tekan yang didapatkan sebesar $14.39 \mathrm{kgf}$

Tekanan maksimum yang dapat diterima oleh briket diperoleh dengan persamaan :

$$
P_{\max } \quad=\frac{F}{A}
$$

Dimana :

$$
\begin{aligned}
& \mathrm{F}=\text { gaya tekan }=14.39 \mathrm{kgf} \\
& \mathrm{A}=\text { Luas bidang tekan }\left(\mathrm{cm}^{2}\right)
\end{aligned}
$$

Luas penampang luar briket dengan diameter $6.5 \mathrm{~cm}\left(\mathrm{D}_{\mathrm{o}}\right)$

$$
\mathrm{A}_{\mathrm{o}}=1 / 4 \pi \mathrm{D}_{\mathrm{o}}^{2}=1 / 4.3 \cdot 14 \cdot(6.5)^{2}=33.166 \mathrm{~cm}^{2}
$$

Luas lubang briket dengan diameter $1.5 \mathrm{~cm}\left(\mathrm{D}_{\mathrm{i} 1}\right)$

$$
\mathrm{A}_{\mathrm{i} 1}=1 / 4 \pi \mathrm{D}_{\mathrm{i} 1}^{2}=1 / 4.3 \cdot 14 \cdot(1.5)^{2}=1.766 \mathrm{~cm}^{2}
$$

Luas lubang briket dengan diameter $0,8 \mathrm{~cm}\left(\mathrm{D}_{\mathrm{i} 2}\right)$

$$
\mathrm{A}_{\mathrm{i} 2}=1 / 4 \pi \mathrm{D}_{\mathrm{i} 12}{ }^{2}=1 / 4.3 \cdot 14 \cdot(0.8)^{2}=0.502 \mathrm{~cm}^{2}
$$


Terdapat 4 lubang maka seluruh luas seluruh lubang briket

$$
\mathrm{A}_{\mathrm{i} 2}=4 \times 0.502 \mathrm{~cm}^{2}=2.0096 \mathrm{~cm}^{2}
$$

Jadi luas total permukaan briket yang didalam

$$
\mathrm{A}_{\mathrm{i}}=\mathrm{A}_{\mathrm{i} 1}+\mathrm{A}_{\mathrm{i} 2}=1.766 \mathrm{~cm}^{2}+2.0096 \mathrm{~cm}^{2}=3.776 \mathrm{~cm}^{2}
$$

Jadi luas total briket

$$
A=A_{o}-A_{i}=33,166 \mathrm{~cm}^{2}-3.776 \mathrm{~cm}^{2}=29.39 \mathrm{~cm}^{2}
$$

Jadi Tekanan yang didapatkan

$$
P_{\max }=\frac{F}{A}=\frac{14.39 \mathrm{~kg}}{29.39 \mathrm{~cm}^{2}}=0.489 \mathrm{~kg} / \mathrm{cm}^{2}
$$

2) Kerapatan

Kerapatan (densitas) briket diperoleh dengan menggunakan persamaan :

$$
\rho=\frac{m}{V \text { total }}
$$

Dimana : $\mathrm{m}=$ massa briket $(\mathrm{gr})=93.3 \mathrm{gr}$

$$
\mathrm{V}_{\text {total }}=\text { Volume total briket }\left(\mathrm{cm}^{3}\right)
$$$$
=132.2568 \mathrm{~cm}^{3}
$$

Sehingga :

$$
\rho=\frac{m}{V_{\text {total }}}=\frac{93.3 \mathrm{gr}}{132.2568 \mathrm{~cm}^{3}}=0.705 \mathrm{gr} / \mathrm{cm}^{3}
$$

4. Pengujian pembakaran dan efisiensi pembakaran

a. Pembakaran briket

Data pengujian pembakaran briket pada kompor briket dengan metode pendidihan air pada 3 (tiga) jenis kompor sebelum dan setelah modifikasi berupa waktu pembakaran setiap 5 menit, temperatur api, temperatur air, massa air dan massa briket sebelum dan setelah pembakaran, massa uap, massa briket yang terbakar, massa jenis tetap air dan panci dan nilai kalor briket. Hasil grafik temperatur versus waktu pembakaran briket pada 6 jenis kode kompor yang diteliti yaitu Gambar sebelum modifikasi dan setelah modifikasi pada 3 jenis kompor yang berbedadalam hal kemampuan mendidihkan air dan temperatur maksimal apinya dapat dilihat pada Gambar dan tabel hasil pengujian dibawah ini.

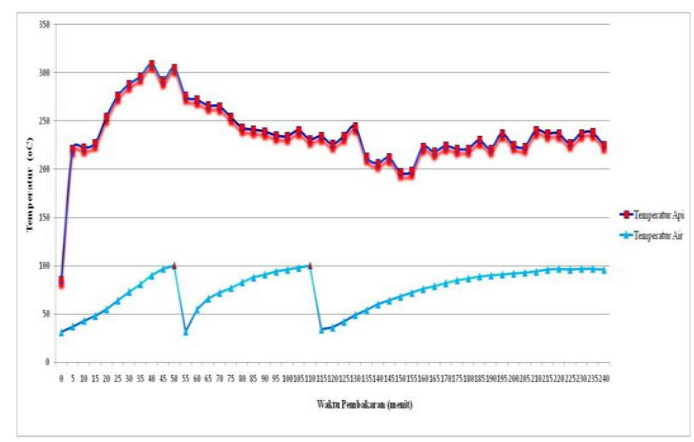


Gambar 7. Grafik temperatur versus waktu pembakaran pada kompor K1

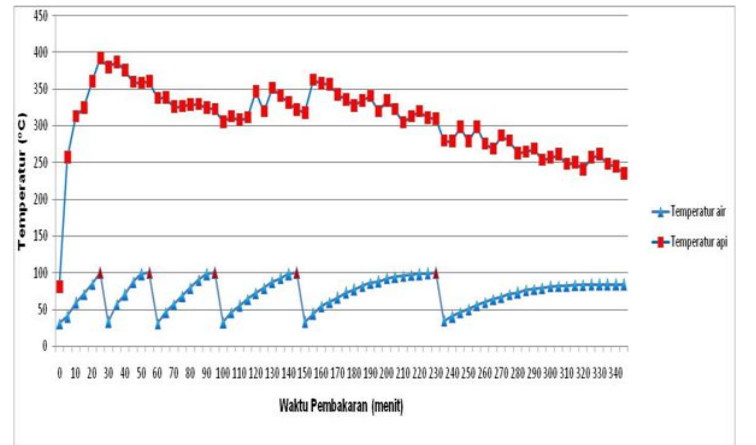

Gambar 8 Grafik temperatur versus waktu pembakaran pada kompor $K^{\prime} 1$
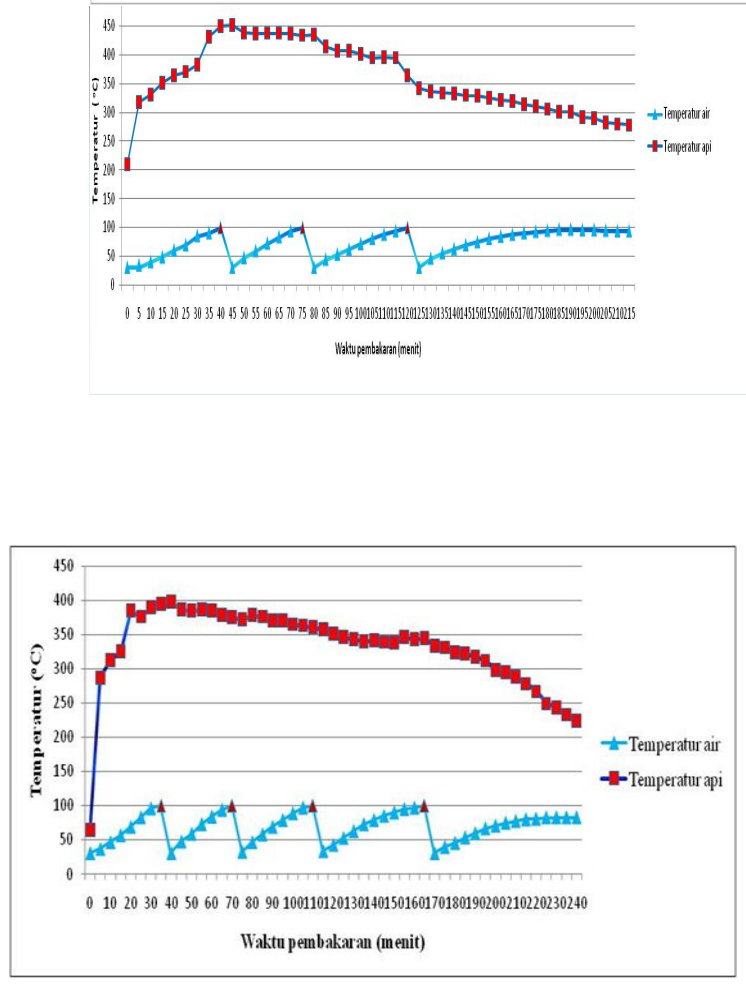

Gambar 9. Grafik temperatur versus waktu pembakaran pada kompor $\mathrm{K} 2$

Gambar 10. Grafik temperatur versus waktu pembakaran pada kompor K'2

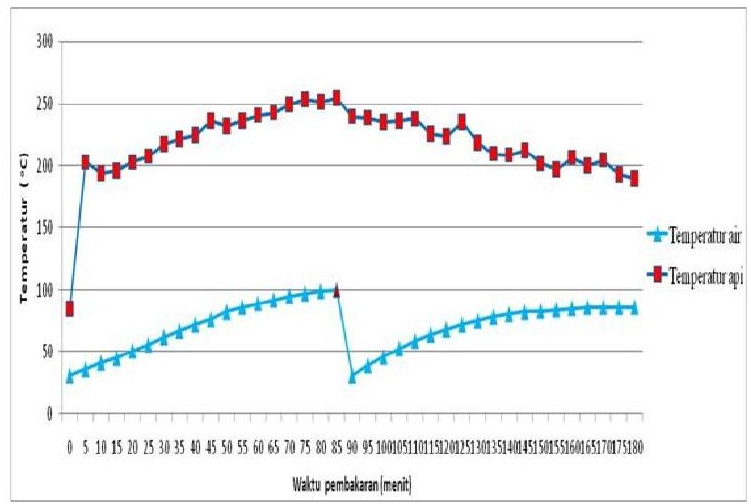




\section{Gambar 11. Grafik temperatur versus waktu pembakaran pada kompor K3}

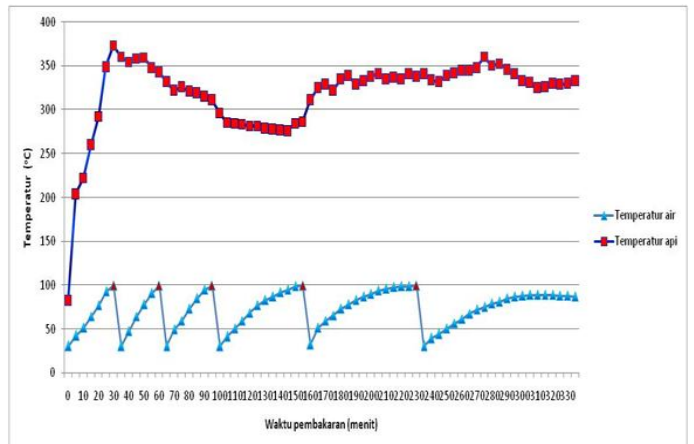

Gambar 12. Grafik temperatur versus waktu pembakaran pada kompor K'3

Gambar 7-8 merupakan grafik hubungan antara temperatur terhadap waktu pembakaran briket pada kompor K1 sebelum dan setelah modifikasi. Terlihat Gambar 2 bahwa kemampuan mendidihkan air kompor K1 sebelum modifikasi hanya sebanyak 2 kali pada menit ke 48 dan menit ke 123 (garis warna biru), tidak bisa mendidihkan lagi hanya memanaskan air sampai 96 ${ }^{\circ} \mathrm{C}$ dengan pengambaran temperatur api dengan warna merah, dimana temperatur maksimum api sebesar $309^{\circ} \mathrm{C}$. Dan dibandingkan pada Gambar 3 kompor K1 setelah modifikasi yaitu kompor K'1 dalam mendidihkan air sebanyak 5 kali pada menit ke 24, 51, 91, 142, dan 229 (garis warna biru), hanya memanaskan air sampai $96^{\circ} \mathrm{C}$ dengan pengambaran temperatur api dengan warna merah. Dimana temperatur maksimum apinya sebesar $393^{\circ} \mathrm{C}$.

Gambar 9-10 merupakan grafik hubungan antara temperatur terhadap waktu pembakaran briket pada kompor K2 sebelum dan setelah modifikasi. Terlihat Gambar 4 bahwa kemampuan mendidihkan air kompor K2 sebelum modifikasi sebanyak 3 kali pada menit ke 31, 67, dan 111 (garis warna biru), tidak bisa mendidihkan lagi hanya memanaskan air sampai $94{ }^{\circ} \mathrm{C}$ dengan pengambaran temperatur api dengan warna merah, dimana tenperatur maksimum api sebesar $451{ }^{\circ} \mathrm{C}$. Dan dibandingkan dengan Gambar 5 kompor K1 setelah modifikasi yaitu kompor K'2 dalam kemampuan mendidihkan air sebanyak 4 kali pada menit ke 31, 67, 107 dan 165 (garis warna biru), hanya memanaskan air sampai $83^{\circ} \mathrm{C}$ dengan pengambaran temperatur api dengan warna mera. Dimana temperature maksimum apinya sebesar $398^{\circ} \mathrm{C}$.

Gambar 11-12 merupakan grafik hubungan antara temperatur terhadap waktu pembakaran briket pada kompor K3 sebelum dan setelah modifikasi. Terlihat Gambar 6 bahwa kemampuan mendidihkan air kompor K3 sebelum modifikasi hanya sebanyak 1 kali pada menit ke 83 (garis warna biru), tidak bisa mendidihkan lagi hanya memanaskan air sampai $86{ }^{\circ} \mathrm{C}$ dengan pengambaran temperatur api dengan warna merah, dimana temperatur maksimum api sebesar $255^{\circ} \mathrm{C}$. Dan dibandingkan pada Gambar 7 kompor K3 setelah modifikasi yaitu kompor K'3b dalam mendidihkan air sebanyak 5 kali pada menit ke 27, 58, 93, 157, dan 227 (garis warna 
biru), hanya memanaskan air sampai $87^{\circ} \mathrm{C}$ dengan pengambaran temperatur api dengan warna merah. Dimana temperature maksimum apinya sebesar $373^{\circ} \mathrm{C}$.

\section{b. Efisiensi pembakaran}

Sebagai contoh perhitungan diambil efisiensi termal untuk kompor K1 dalam mendidihkan air sebanyak 2 kali dan temperatur api di dapatkan sebesar $309{ }^{\circ} \mathrm{C}$ dengan waktu pembakaran briket selama 240 menit (4 jam). Dan menghabiskan briket yang terbakar sebanyak $0.22 \mathrm{~kg}$. Selanjutnya dapat dilihat data-datanya sebagai berikut :

- $\mathrm{m}_{\mathrm{a}} \quad=$ massa air yang dipanaskan $(\mathrm{kg})=0.8 \mathrm{~kg}$

- $\quad \mathrm{m}_{\mathrm{p}} \quad=$ massa panci $(\mathrm{kg})=0.18 \mathrm{~kg}$

- $\mathrm{m}_{\mathrm{bk}}=$ massa briket yang telah terpakai $(\mathrm{kg})$

- $\mathrm{m}_{\mathrm{u}} \quad$ = massa uap air $(\mathrm{kg})=0.08 \mathrm{~kg}$

- $\mathrm{H}_{L}=$ kalor laten dari uap $(\mathrm{kJ} / \mathrm{kg})=2256.487 \mathrm{~kJ} / \mathrm{kg}$

- $\mathrm{Cp}_{\text {air }}=$ kalor spesifik air $\left(\mathrm{kJ} / \mathrm{kg}{ }^{0} \mathrm{C}=4.1769 \mathrm{~kJ} / \mathrm{kg}{ }^{0} \mathrm{C}\right.$

- $\mathrm{Cp}_{\mathrm{al}}=$ kalor spesifik aluminium $\left(\mathrm{kJ} / \mathrm{kg}{ }^{0} \mathrm{C}\right)=0.9 \mathrm{~kJ} / \mathrm{kg}{ }^{0} \mathrm{C}$

- $L H V=$ nilai kalor bawah briket $(\mathrm{kJ} / \mathrm{kg})$

$$
=(20719,48 \mathrm{~kJ} / \mathrm{kg}-3240 \mathrm{~kJ} / \mathrm{kg})=17479.48 \mathrm{~kJ} / \mathrm{kg}
$$

- $\mathrm{T}_{\mathrm{b}}=$ temperatur air awal $\left({ }^{\circ} \mathrm{C}\right)=31^{\circ} \mathrm{C}$

- $\mathrm{T}_{\mathrm{a}}=$ temperatur didih air dalam panci $\left({ }^{\circ} \mathrm{C}\right)=100{ }^{\circ} \mathrm{C}$

- $\mathrm{T}_{\mathrm{c}} \quad=$ temperatur api $\left({ }^{\circ} \mathrm{C}\right)=309^{\circ} \mathrm{C}$

Dengan menggunakan persamaan, maka diperoleh efisiensi termal sebagai berikut :

$\eta_{t}=\frac{(0.8 \times 4.1769 x(2 r(100-31)+(96-34))+0.18 \times 0.9 x((309-31)+(240-31)+(225-34))+(2256.487 \mathrm{r} 0.08)}{0.22 \times(17479.48)}$

$\eta_{\mathrm{i}}=\frac{958.65896}{3845.4896} \mathrm{rl} 100 \%=24.96 \%$
Hasil perbandingan dari data pengujian 3 jenis kompor sebelum dan setelah modifikasi dalam kemampuan dan waktu mendidihkan air, temperatur maksimum api, efisiensi thermal serta

briket yang habis terbakar selanjutnya dapat dilihat pada Tabel 2 di bawah ini.

Tabel 4. Tabulasi peningkatan kinerja kompor

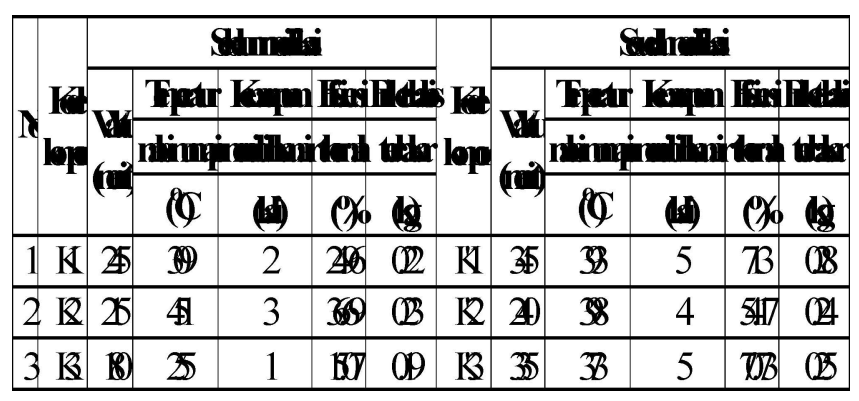

Tabel 4 merupakan tabel tabulasi peningkatan kinerja kompor yang diteliti sebelum dan setelah modifikasi. Dapat dilihat untuk kompor K1 sebelum modifikasi memiliki temperatur maksimum api, kemampuan mendidihkan air, efisensi thermal dan massa briket yang habis terbakar masing-masing sebesar $309{ }^{\circ} \mathrm{C}, 2$ kali dalam waktu 240 menit, $24.96 \%$. Setelah modifikasi pada kompor K'1 sebesar $393^{\circ} \mathrm{C}$, 5 kali dalam waktu 345 menit dan efisiensi 71.30\%. Pada kompor K2 sebelum modifikasi masing-masing sebesar $451^{\circ} \mathrm{C}, 3$ kali dalam waktu 215 menit dan efisiensi sebesar $36.69 \%$. Dan setelah modifikasi pada kompor K'2 sebanyak 4 kali mendidihkan air dalam waktu 240 menit, temperatur maksimum apinya $398{ }^{\circ} \mathrm{C}$ dan efisiensinya sebesar $54.17 \%$. Dan terakhir $\mathrm{K} 3$ sebelum modifikasi menghasilkan temperature, kemampuan mendidihkan air, efisiensi masing-masing sebesar $255^{\circ} \mathrm{C}, 5 \mathrm{kali}$ dalam waktu 180 menit, 15.07\%. Dan didapatkan setelah modifikasi kompor K'3 dalam mendidihkan air sebanyak 5 kali dalam waktu 335 menit, $373^{\circ} \mathrm{C}$, dan $70.73 \%$.

B. Pembahasan

Pembuatan briket dilakukan dalam bentuk sarang tawon dengan dimensi diameter $65 \mathrm{~mm}$, tinggi 45 meter 1 lubang tengah $15 \mathrm{~mm}$ dan 4 lubang kecil dengan diameter $8 \mathrm{~mm}$. Hasil pengujian proksimasi, nilai kalor serta sifat fisiknya rata-rata yaitu kadar air $1.67 \%$, kadar abu $13.03 \%$, volatile matters $28.61 \%$, fixed carbon $56.69 \%$, nilai kalor $4949 \mathrm{kkal} / \mathrm{kg}$, kerapatannya $0.705 \mathrm{gr} / \mathrm{cm}^{3}$ dan kuat tekan $0.489 \mathrm{gr} / \mathrm{cm}^{2}$. Hasil pengujian ini menunjukkan belum memenuhi standar briket, kecuali kadar air dan volatile matters. Walaupun usaha perbaikan kualitas dengan cara memperbaiki proses pengarangan (mengurangi abu) dan 
proses pengeringan (mengurangi kadar air) serta penggunaan partikel saringan optimal 40-60 mesh telah dilakukan

Kompor K1 sebelum modifikasi hanya 2 kali mendidihkan air dengan temperatur maksimumnya $309^{\circ} \mathrm{C}$ dan efisiensi $24.92 \%$. Dan setelah modifikasinya yaitu pada kompor K'1 mengalami pendidihan air sebanyak hampir lebih 5 kali dengan temperaturnya $393{ }^{\circ} \mathrm{C}$, efisiensinya $71.30 \%$. Hal ini disebabkan karna modifikasi penambahan plat silinder aluminium satu baris lubang diatas yang mampu mempertahankan panas api briket hampir lebih dari 5 jam.

Pada kompor K2 sebelum modifikasi menghasilkan 3 kali pendidihan dengan temperaturnya $451^{\circ} \mathrm{C}$ dan efisiensinya $36.69 \%$. Kompor K2 juga paling baik sebelum modifikasi karna penyusunan briket dalam ruang bakar disusun secara mendatar. Dan setelah dilakukan modifikasi variasi 24 lubang dengan isolasi asbes dan seng diikat dengan kawat yaitu kompor K'2. Sehingga peningkatan kinerja pun terjadi dengan 1 lipat lipat dari modifikasi yang telah dilakukan dengan proses pendidihan air menjadi 4 kali.

Kompor K3 sebelum modifikasi hanya 1 kali mendidihkan air dengan temperatur apinya $255{ }^{\circ} \mathrm{C}$ dan efisiensi $15.70 \%$. Setelah modifikasi pada kompor K'1 didapatkan kemampuan mendidihkan air sebanyak 5 kali dengan temperaturnya yang tidak telalu tinggi sebesar $373{ }^{\circ} \mathrm{C}$ dan efisiensi $70.73 \%$. Hal ini disebabkan modifikasi penambahan plat silinder aluminium satu baris lubang dibagian atas yang juga mampu mempertahankan nyala api briket 335 menit.

\section{KESIMPULAN DAN SARAN}

\section{A. Kesimpulan}

Briket telah dibuat dalam bentuk sarang tawon, dengan ukuran diameter $65 \mathrm{~mm}$, tinggi $45 \mathrm{~mm}$, satu lubang tengah $15 \mathrm{~mm}$, empat buah lubang berdiameter $8 \mathrm{~mm}$. Hasil pengujian proksimasi rata-rata yaitu kadar air $1.67 \%$, kadar abu $13.03 \%$, volatile matters $28.61 \%$, fixed carbon $56.69 \%$. Nilai kalor didapatkan sebesar $4949 \mathrm{kkal} / \mathrm{kg}$, kuat tekan sebesar $0.489 \mathrm{gr} / \mathrm{cm}^{2}$ dan kerapatannya sebesar 0.705 $\mathrm{gr} / \mathrm{cm}^{3}$. Hasil keseluruhan pengujian proksimasi dan sifat fisiknya belum memenuhi standar mutu briket yang ada, kecuali kadai air dan volatile matters.

Hasil pengujian kinerja 3 jenis kompor sebelum modifikasi diperoleh : bahwa Kompor K2 paling unggul dalam hal kemampuan mendidihkan air, temperatur maksimum api, efisiensi thermal masingmasing sebesar yaitu 3 kali dalam waktu 215 menit, $451^{\circ} \mathrm{C}$ dan $36.69 \%$. Disusul kompor K1 dengan 2 kali mendidihkan air dalam waktu 240 menit, $309{ }^{\circ} \mathrm{C}$ dan $24.92 \%$. Dan paling rendah adalah kompor K3 hanya mendidihkan air sebanyak 1 kali dalam waktu 180 menit, $255^{\circ} \mathrm{C}$ dan efisiensinya sebesar $15.70 \%$. Kemampuan mendidihkan air dan efisiensi thermal yang paling baik setelah modifikasi yaitu dihasilkan kompor K'1 dan kompor K'3 sebanyak 5 kali, dimana kompor K'3 lebih cepat 10 menit dari kompor K'1c Dengan efisiensi masing-masing kompor K'1c sebesar $71.30 \%$ dan kompor K'3 sebesar $70.73 \%$. Dari keseluruhan pengujian kompor baik sebelum dan sesudah modifikasi yang paling unggul adalah kompor K'1 dan kompor K'3. Kedua kompor tersebut memiliki keunggulan masing-masing, dimana kompor K'1 sedikit lebih unggul dari segi efisiensi thermal dan temperatur maksimum apinya. Tetapi kompor K'3 unggul dalam waktu penyalaan dan juga memiliki keunggulan tambahan karna dapat diproduksi secara lokal (dari tanah liat) dan harganya terjangkau. Peningkatan efisiensi terbaik didapatkan untuk kompor K1 sebesar $46.34 \%$ (dari $24.96 \%-71.30 \%$ ), untuk kompor K2 sebesar 17.485 (dari $36.69 \%-54.17 \%$ ) dan kompor K3 sebesar 55.03\% (dari 15.70-70.73\%)

\section{B. Saran}

Peningkatan kinerja telah berhasil dilakukan pada 3 jenis kompor yang berbeda. Tetapi masih ada kekurangan yang ditemukan dalam penelitian ini yaitu proses pendidihan air (waktu memasak) yang cukup lama dan jumlah bahan yang dimasak sedikit. Oleh karna itu perlu dilakukan penelitian lanjutan khususnya dalam hal mendesain kompor yang optimal dengan kapasitas bahan bakar yang lebih banyak dan lebih banyak bahan yang dapat dimasak dalam waktu yang relatif lebih singkat. Dan perlukan juga dilakukan untuk pengujian emisi

\section{DAFTAR PUSTAKA}

[1] Kuncoro Heru dan Damanik Ladjiman (2005) Kompor Briket Batubara Tanpa BBM Dan Hemat Biaya. Penebar Swadaya, Jakarta 2005. 
[2] MM Faozi., 2008. Peluang Pasar Produk dari Kelapa Indonesia, Analisa Dampak Menipisnya Cadangan Minyak Bumi Dan Perubahan Iklim. Http://www.mmfaozi.com/peluang pasar,dll. Diaskes 11 Februari 2009.

[3] Arif, E,.2008. Pemanfaatan Briket Limbah Biomassa Sebagai Sumber Energy Alternatif. Laporan Penelitian Fakultas Teknik Universitas Hasanuddin Makassar

[4 Mahadir Sirman., 2013. Peningkatan Kualitas Briket Campuran Limbah Ketam Kayu Merbabu, Sekam Padi dan Tongkol Jagung Pada Berbagai Komposisi. Laporan Penelitian Fakultas Teknik Universitas Hasanuddin.

[5] Syahrir M., 2011. Limbah Batang Jagung Sebagai sumber Energi Alternatif. Laporan Penelitian Fakultas Teknik Universitas Hasanuddin.

[6] Mangkau A (2011). Karakteristik Pembakaran Briket limbah Tongkol Jagung dan Sekam Padi Dengan Berbagai Perbandingan Tongkol Jagung Dan Sekam Padi. Laporan Penelitian Fakultas Teknik Universitas Hasanuddin.

[7] Jamilatun S., 2011. Kualitas sifat-sifat dari pembakaran tempurung kelapa, briket serbuk gergaji kayu jati, briket sekam dan briket batubara. Prosiding seminar Nasional Teknik Kimia"Kejuangan” Universitas Ahmad Dahlan Yogyakarta.

[8] Jamilatun S., 2008. Sifat-Sifat Penyalaan dan Pembakaran Briket Biomassa, briket batu bara dan Arang Kayu. Jurnal Rekaya proses., Vol. 2, no. 2, 2008.

[9] Siwi H (2010). Pemanfaatan Limbah Tempurung Kelapa dan Enceng Gondok Sebagai Sumber Alternatif. Laporan Penelitian Tesis Fakultas Teknik Universitas Hasanuddin

[10] Esmar Budi., 2011. Tinjauan Proses Pembentukan dan Penggunaan Arang Tempurung Kelapa sebagai Bahan Bakar. Jurnal Penelitian Sains Vol. 4, No. 3(B), Oktober 2011.

[11] Meli dan Muslimin (2010). Pengaruh Dimensi Arang Tempurung Kelapa Terhadap Mutu Briket. Skripsi S1 Teknik Mesin Fakultas Teknik Universitas Hasanuddin.

[12] Arianto (2010). Daun Kering Kakao dan Daun Kering Kayu Jati Dijadikan Sebagai Energi Alternatif.

Skripsi S1 Teknik Mesin Fakultas Teknik Universitas Hasanuddin. 